\title{
Effectivity of hand washing technique using World Health Organization (WHO) method with an ultraviolet light assessment on health workers at Department Oral and Maxillofacial Surgery, Faculty of Dentistry, Universitas Sumatera Utara February-March 2018
}

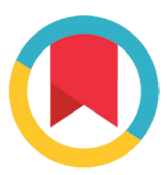

CrossMark

\author{
Olivia A. Hanafiah, Isnandar, Indra B. Siregar, Lung L. Wong
}

Abstract

Objective: This study aim to determine the effectivity of hand washing technique using the World Health Organization (WHO) method with ultraviolet light assessment on health workers at Department of Oral and Maxillofacial Surgery, Faculty of Dentistry, Universitas of Sumatera Utara February-March 2018.

Material and Methods: This study was an experimental study with a one group pre-test post-test group design. The sampling method used in this study was purposive sampling. 18 undergraduate students in the Department of Oral and Maxillofacial Surgery part- icipated as subjects of this study. Sample was assessed before and after hand washing using WHO method.

Results: Hand washing technique using WHO method was effective on the palm, back of hands, between fingers, and thumbs $(p<0.05)$ while on fingertips was not effective $(p>0.05)$.

Conclusion: Effectivity of hand washing technique using WHO method with the ultraviolet light assessment on health workers at Department of Oral and Maxillofacial Surgery, Faculty of Dentistry, Universitas Sumatera Utara February - March 2018 was effective.
Department of Oral and Maxillofacial Surgery, Faculty of Dentistry, Universitas Sumatera Utara, Medan, Indonesia

*Correspondence to: Isnandar, Department of Oral and Maxillofacial Surgery, Faculty of Dentistry, Universitas Sumatera Utara, Medan, Indonesia

isnandar@usu.ac.id

Received: 15 August 2018 Revised: 28 February 2019 Accepted: 5 March 2019 Available online 1 April 2019

Keywords: Hand washing technique, Ultraviolet light assessment, WHO method

Cite this Article: Hanafiah OA, Isnandar, Siregar IB, Wong LL. 2019. Effectivity of hand washing technique using World Health Organization (WH0) method with an ultraviolet light assessment on health workers at Department Oral and Maxillofacial Surgery, Faculty of Dentistry, Universitas Sumatera Utara February-March 2018. Journal of Dentomaxillofacial Science 4(1): 7-11. D0I:10.15562/jdmfs.v4i1.791

\section{Introduction}

A dentist has high risk of getting infected and also can transmit infection from patient to another patient (cross-infecti on). ${ }^{1}$ Transmission of infection is one of the most common problems in global healthcare. Infection prevention and control of cross-contamination is essential to establish a safe environment for patients and healthcare workers to maintain general health and more specifically in dental practice. ${ }^{2}$ All healthcare personnel have the responsibility to perform correct aseptic techniques and infection control to avoid the risk of cross infection. ${ }^{1-4}$

An unsterile dental procedure and healthcare personnel who didn't follow the standard operating procedures while performing health services can cause disease transmission. ${ }^{5}$ Various diseases like hepatitis $B$, herpes simplex virus, tuberculosis and influenza can be transmitted during treatment. ${ }^{1,5-8}$

In Indonesia, the incedence of cross-infection is quite high in the hospital, about $6-16 \%$ with average of $9.8 \%$. There is a very high risk for the dentist to the get infected when performing tooth extraction because this action can cause a direct contact with blood, saliva and contaminated tools. 9,10 WHO stated that increasing in hand washing compliance from poor category $(60 \%)$ to very good category $(90 \%)$ can decrease the risks of cross infection by $24 \%$. Other studies also mention that hand washing compliance encourages a decrease in MRSA infection (methicillin-resistant staphyloccous aureus) by $48.2 \%-87 \% .{ }^{11-14}$ Therefore, the correct hand washing technique is vital in preventing cross-infection during dental procedures.

\section{Material and Methods}

This study was an experimental study with one group pre-test post-test group design. The sampling method used in this study was purposive sampling in which sample in this study was 18 undergraduate students at Department of Oral and Maxillofacial Surgery in Faculty of Dentistry, Universitas Sumatera Utara that are willing to participate in this study. Sample must fulfill the inclusion criteria: hands must be in clean condition; free from wounds and other diseases; didn't wear a watch, ring, and other accessories; and the nails must be short and without nail accessories.

Sample was given an explanation about this research procedure and filled the informed consent. Samples were given a glo germ figure 1 . Then the gel was applied on hands and wipe it evenly thorough all hand surfaces. Hands were air-dry and checked under ultraviolet light assessment figure 2. Result was recorded and after that sample was instructed to wash their hands using WHO method.

Hands were checked again under ultraviolet- 


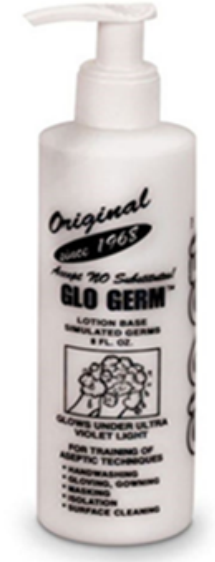

Figure 1 Glo Germ

light and result was recorded. Data obtained from this experiment was put into a table. Data processing was done with computer analyzed using McNemar's test.

\section{Results}

Results obtained from 18 health workers at Department of Oral and Maxillofacial Surgery, Faculty of Dentistry, Universitas Sumatera Utara. The effectivity of hand washing technique was analyzed using McNemar test. Results showed hand washing technique using WHO method was effective on the palm, back of hands, between fingers and thumbs $(\mathrm{p}<0.05)$ while on fingertips was not effective $(\mathrm{p}>0.05)$.

Table 1 showed the result obtained from 18 health workers at Department of Oral and Maxillofacial Surgery, Faculty of Dentistry, Universitas Sumatera Utara. Results showed that the assessment of dirty area before hand washing using WHO method can be seen in table 1. The results were divided into two: dirty ( $>50 \%$ of bright areas) and clean ( $<50 \%$ of bright areas). Results can be seen in table 1 where for the palms and back of hands, there was only 1 sample (5.6\%) with clean hands and 17 samples (94.4\%) with dirty hands. In thumbs, there was 2 samples (11.1\%) with clean hands and 16 samples (88.9\%) with dirty hands. For the in between fingers areas, there was 3 samples (16.7\%) with clean hands and 15 samples (83.3\%) with dirty hands, while in fingertips, there was 6 samples (33.3\%) with dirty hands and 12 samples (66.7\%) with clean hands as shown in.

Results showed that the assessment of dirty area after hand washing using WHO method can be seen in table 2. For the palms and between fingers areas, there was 17 samples (94.4\%) with clean hands and only 1 sample (5.6\%) with dirty hands. In back of hands and thumbs, there was
16 samples (88.9\%) with clean hands and 2 samples (11.1\%) with dirty hands. In fingertips, there was 9 samples (50\%) with dirty hands and 9 samples (50\%) with clean hands.

The effectivity of hand washing technique was analyzed using McNemar test table 3. Results showed hand washing technique using WHO method was effective in the palm, back of hands, between fingers, and thumbs $(\mathrm{p}<0.05)$ while in fingertips was not effective ( $p>0.05)$.

Based on the results of observations, there were five areas of both hands assessed before and after hand washing, which were palms figure 3, back of hands figure 4 , between fingers, fingertips figure 5 and thumbs.

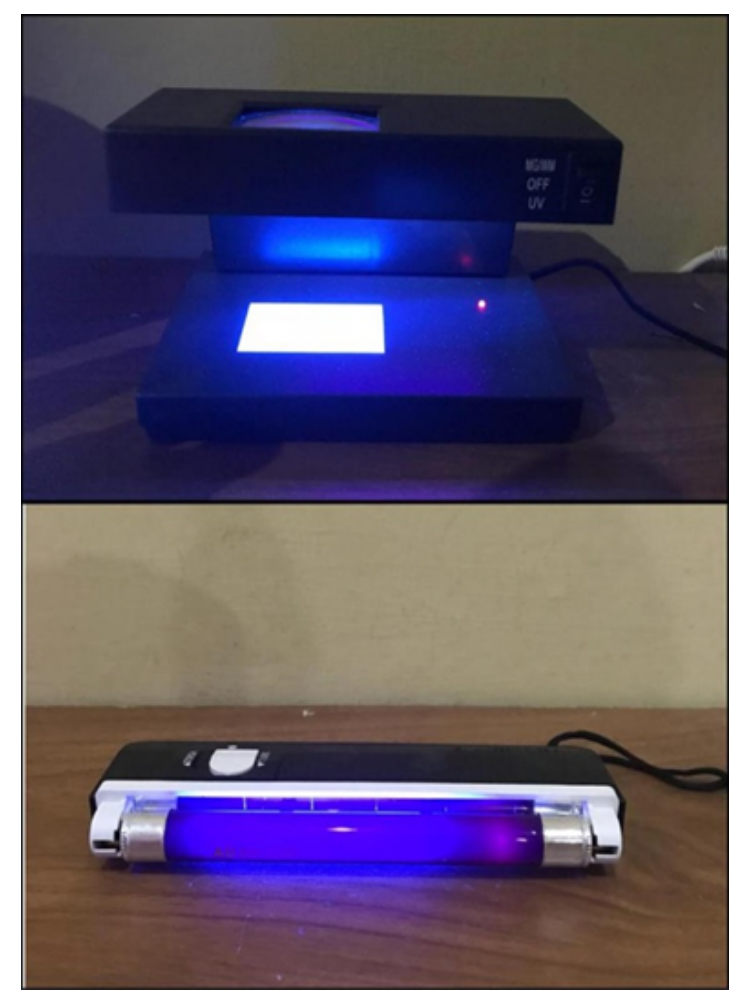

Figure 2 Ultraviolet Light

\section{Discussion}

In general, the effectivity of hand washing technique using WHO method on health workers at Department of Oral and Maxillofacial Surgery was effective. From the total 18 subjects, 12 subjects showed changes from poor to good category, 3 subjects had changes from moderate to good and 3 subjects improved from poor to moderate category after hand washing using WHO method.

Results using the McNemar test showed that there was a difference in effectivity before and after hand washing using WHO method. Assessment can be categorized as effective if the bright areas 
Table 1 The results of samples hand hygiene before hand washing

\begin{tabular}{|c|c|c|c|c|}
\hline \multirow{3}{*}{ Hand areas } & \multicolumn{4}{|c|}{ Percentage of bright areas } \\
\hline & \multicolumn{2}{|c|}{$<50 \%$ (clean) } & \multicolumn{2}{|c|}{$>50 \%$ (dirty) } \\
\hline & $\mathbf{N}$ & $\%$ & $\mathbf{N}$ & $\%$ \\
\hline Palms & 1 & 5.6 & 17 & 94.4 \\
\hline Back of hands & 1 & 5.6 & 17 & 94.4 \\
\hline Between fingers & 3 & 16.7 & 15 & 83.3 \\
\hline Fingertips & 6 & 33.3 & 12 & 66.7 \\
\hline Thumbs & 2 & 11.1 & 16 & 88.9 \\
\hline
\end{tabular}

Table 2 The results of samples hand hygiene after hand washing

\begin{tabular}{|c|c|c|c|c|}
\hline \multirow{3}{*}{ Hand areas } & \multicolumn{4}{|c|}{ Percentage of bright areas } \\
\hline & \multicolumn{2}{|c|}{$<50 \%$ (clean) } & \multicolumn{2}{|c|}{$>50 \%$ (dirty) } \\
\hline & $\mathbf{N}$ & $\%$ & $\mathbf{N}$ & $\%$ \\
\hline Palms & 17 & 94.4 & 1 & 5.6 \\
\hline Back of hands & 16 & 88.9 & 2 & 11.1 \\
\hline Between fingers & 17 & 94.4 & 1 & 5.6 \\
\hline Fingertips & 9 & 50 & 9 & 50 \\
\hline Thumbs & 16 & 88.9 & 2 & 11.1 \\
\hline
\end{tabular}

\section{Table 3 Data analysis using McNemar test}

\begin{tabular}{lcc}
\hline Hand areas & p value for McNemar test & Note \\
\hline Palms & $0.000^{*}$ & Effective \\
Back of hands & $0.000^{*}$ & Effective \\
Between fingers & $0.000^{*}$ & Effective \\
Fingertips & $0.375^{*}$ & Not Effective \\
Thumbs & $0.000^{*}$ & Effective \\
\hline${ }^{{ }^{p}<0.05}$ & &
\end{tabular}

are eliminated after hand washing and vice versa, the assessment is categorized as ineffective if the bright areas remain in the hands after the hand washing technique. In this study, there were four areas showed effective results and only one area didn't effective after washing hands using the WHO method with the ultraviolet light.

McNemar test showed effective results for palms, back of hands, between fingers and thumbs $(\mathrm{p}<0.05)$, while for fingertips was ineffective $(p>0.05)$. The results showed that after hand washing technique with WHO method, there are still 9 samples (50\%) which shows bright areas (dirty) on the fingertips. These results indicate that the fingertip region is the area most missed by the respondents because this area has cracks that are difficult to clean. Therefore, it is advisable to do surgical hand washing to improve the effectiveness of hand washing. This result was in accordance with research conducted by Manuel Skodova et al, where there were still 33 from 52 people $(63.46 \%)$ that showed an unclean fingertip area. ${ }^{12}$ This is because the presence of fingernails

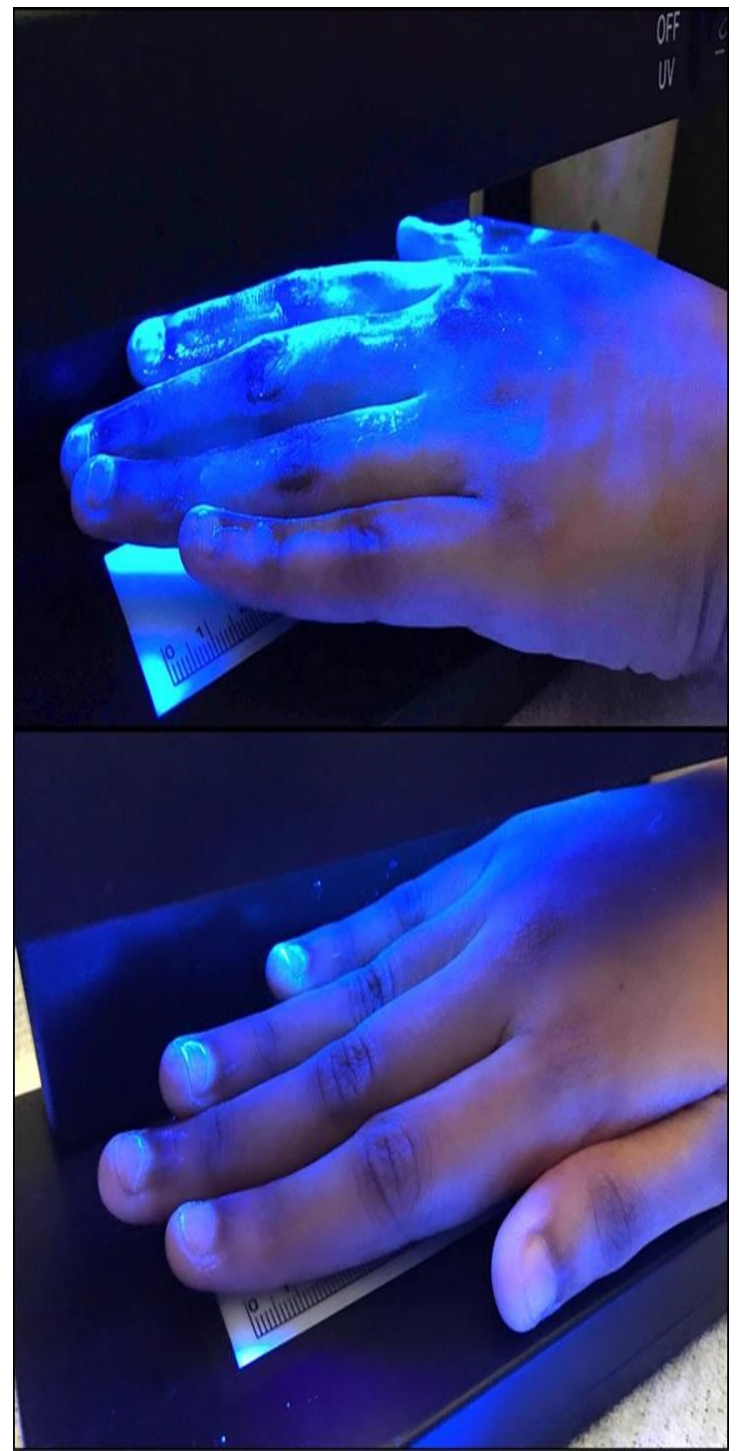

Figure 3 Before and after hand washing technique for back of hand area.

fingertip area.

\section{Conclusion}

The hand washing technique using WHO method with the ultraviolet light assessment on health workers at the Department of Oral and Maxillofacial Surgery was effective. There is a difference in the effectiveness of hand washing techniques after hand washing using the WHO method assessed by ultraviolet light assessment on health workers.

\section{Acknowledgment}

The authors state no funding to declare. 


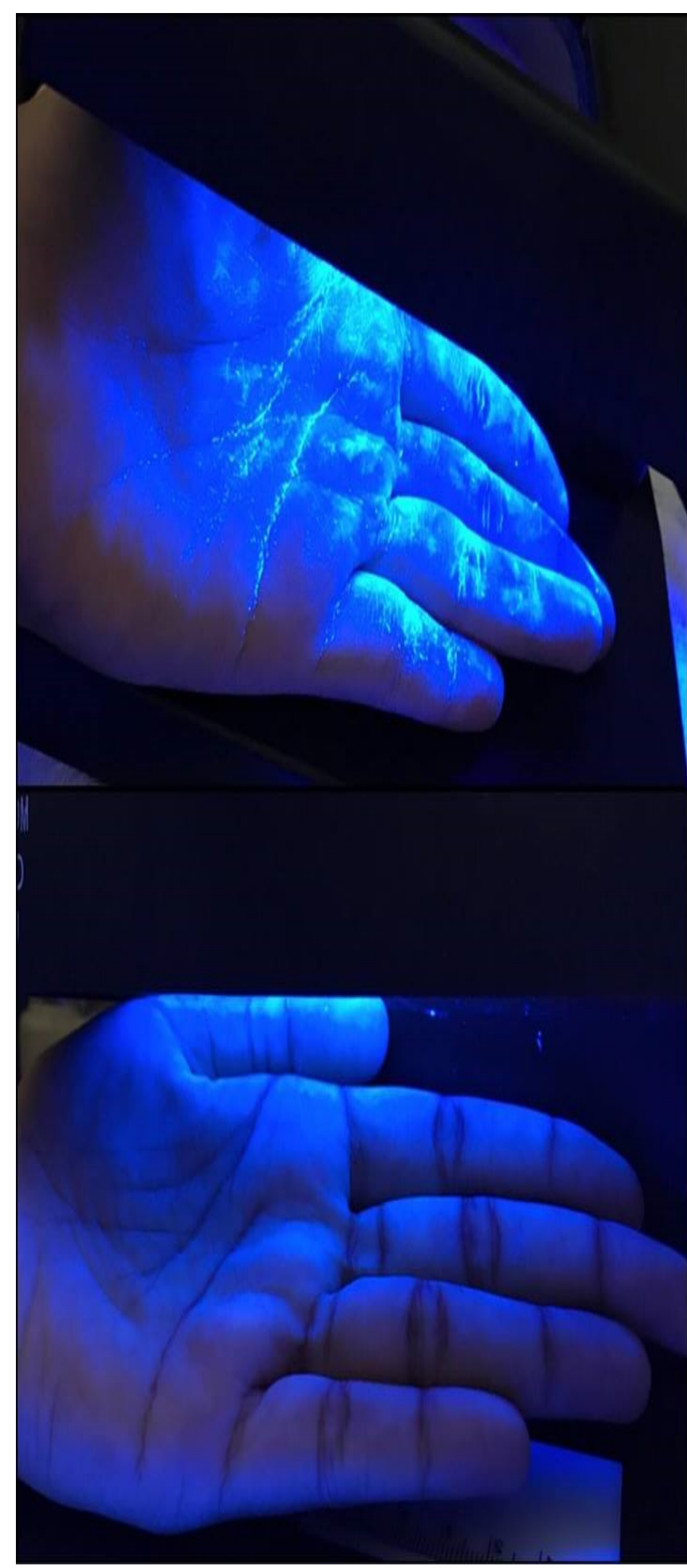

Figure 4 Before and after hand washing technique for palms area.

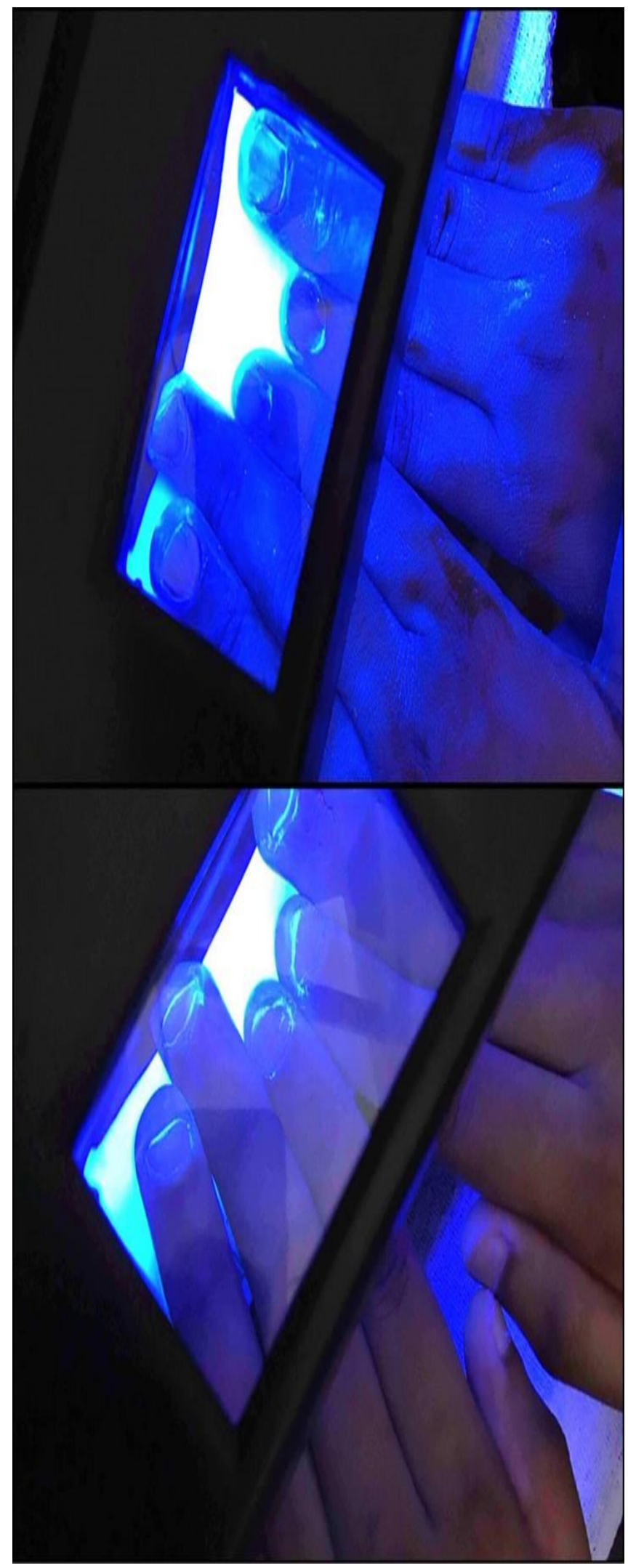

Figure 5 Before and after hand washing technique for fingertips area. 


\section{Conflict of Interest}

The authors report no conflict of interest

\section{References}

1. Edy, Samad R. Upaya pencegahan terhadap bahaya infeksi silang saat melakukan perawatan oleh dokter gigi di Makassar. Dentika Dent J 2012;17: 157-161.

2. Dagher J, Sfeir, Abdallah, et al. Sterilization and Biologic Monitoring in Private Dental Clinics in Lebanon. J Contemp Dent Prac 2018;19:853-861.

3. John. Hand Hygiene: Washing and Disinfection. J Can Dent Assoc 2010;10: 546-547.

4. Rotinsulu AL, Umboh JML, Pongoh. Hubungan antara pengetahuan, ketersediaan sarana dan motivasi dengan kepatuhan penerapan kewaspadaan standar oleh dokter gigi di poliklinik gigi dan mulut Rumah Sakit Kota Manado. J Ikmas 2017;2: 64-80.

5. Mallick, Khaliq, Nasir, et al. Practices of sterilization techniques at dental clinics of Karachi, Pakistan. Int J Pharm 2014;4: 108-112.

6. Noha MA, Eman O, Salwa H. Hand hygiene knowledge and practice among dentists in mansoura Faculty of Dentistry, Egypt. J Med \& Biomed Sci 2016;2: 9-14.

7. Motamedi MHK, Navi F, Valai N, et al. Can oral debris on dental instruments harbor organisms from Disinfection. J Oral Hyg Health 2016;4: 1-2.
8. Devis, ZA F. Metode ceramah dan diskusi kelompok efektif meningkatkan pengetahuan siswa tentang cuci tangan pakai sabun. J Kesehatan Komunitas 2017;3: 159-163.

9. Suleh M, Wowor V, Mintjelungan N. Pencegahan dan pengendalian infeksi silang pada.tindakan ekstraksi gigi di Rumah Sakit Gigi dan Mulut Pspdg Fk Unsrat. J e-GiGi (eG) 2015;3: 1-8.

10. Widmer AF, Dangel M. Alcohol-Based Handrub : Evaluation of Technique and Microbiological Efficacy with International Infection Control Professionals. Chicago J 2004;25: 207-209.

11. Pratama SKR. Faktor determinan kepatuhan pelaksanaan hand hygiene pada perawat IGD RSUD dr. Iskak. J Kedok Brawijaya 2015;28: 195-199.

12. Skodová M, Urra, Benítez A, et al. Hand hygiene assessment in the workplace using a UV lamp. Am J Infec Control 2015;43: 1-2.

13. Purva M. Hand hygiene: back to the basics of infection control. Indian J Med Res 2011;134: 6.

14. Borchgrevink CP, Cha J, Kim S. Hand Washing Practice in a College Town Environment. J Envirement Health 2013;75: 18-24.

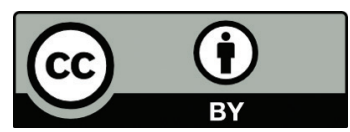

This work is licensed under a Creative Commons Attribution 